\title{
ОСОБЛИВОСТІ ФОРМУВАННЯ МОВЛЕННСВО-КОМУНІКАТИВНОЇ КОМПЕТЕНТНОСТІ НА УРОКАХ ЛІТЕРАТУРНОГО ЧИТАННЯ В 2 - 4 КЛАСАХ
}

\author{
Валерій Сиротенко \\ кандидат філологічних наук, доцент \\ ДВНЗ «Донбаський державний педагогічний університет» \\ м. Слов'янськ Донецької області, Україна \\ valerij.s.kram@gmail.com
}

\section{Анастасія Акритова}

викладач вищої категорії

КЗ «Покровський педагогічний коледж»

м. Покровськ Донецької області, Україна

\begin{abstract}
Анотація. Стаття присвячена розгляду особливостей формування мовленнєвокомунікативної компетентності на уроках літературного читання (2 - 4 класи). На сьогодні це досить актуальна проблема, бо цілеспрямована робота 3 формування мовленнєвокомунікативних якостей належить до одного 3 провідних навчальних завдань Нової української школи, а рівень мовленнєво-комунікативної компетентності - це свідчення особистісної розвиненості учня. На умовах реалізації останнього й робиться наголос у дослідженні, при цьому обираються художні твори, аналіз яких можна здійснювати із застосуванням різних методичних прийомів.

Так, при вивченні народної казки в 2-му класі увага зосереджується на переказуванні тексту (розвиток монологічного мовлення) та роботі в парах (розвиток діалогічного мовлення), але ставиться завдання, щоб діти обов'язково висловлювали своє ставлення до дійових осіб, що позначається на формуванні особистісної життєвої позиції. Пропонуються й завдання творчого характеру: коментар ситуації 3 погляду різних персонажів, зміна інтенційності, чим досягається комунікативне вміння орієнтуватися в ситуації, що виникає, зважаючи при цьому на прагнення оточуючих.

Робота над оповіданням В. Сухомлинського «Соромно перед соловейком» (3-й клас) здійснюється через метод проєкту, завдання якого полягає у формуванні екологічної свідомості учнів як складової частини громадянських якостей особистості.

При аналізові оповідання Гр. Тютюнника «Ласочка» (4-й клас) пропонується звернутися до ігрових вправ, які активізуватимуть інтелектуальні здібності учнів, виробляючи вміння діяти в нестандартній ситуації, із повагою ставитися до співучасника комунікації, утверджуючи вагомі моральні якості особистості.

Ключові слова: мовленнєво-комунікативна компетентність; особистість; діалогічне мовлення; монологічне мовлення; робота в парах; робота в групах; інтенція; метод проєкту; ігрові вправи; екологія; екологічна свідомість; морально-етичні якості.
\end{abstract}

Постановка проблеми в загальному вигляді. Реформування середньої загальноосвітньої школи на сьогодні набуло в Україні перманентного характеру. I для цього є об’єктивні причини. Зараз докорінно змінюються звичні для нас 


\section{В. СИРОТЕНКО, А. АКРИТОВА}

Особливості формування мовленнєво-комунікативної компетентності на уроках літературного читання в $2-4$ класах

методологічні принципи, коли на зміну класово-ідеологічних пріоритетів приходять пріоритети, орієнтовані на утвердження та визнання загальнолюдських цінностей. I ці переорієнтації передусім торкаються школи, адже з ї стін повинна виходити практично сформована особистість із високим рівнем самосвідомості й самоповаги, умінням і здатністю цінувати свободу думки i творчого пошуку, вірою у свої креативні можливості й творчий потенціал, толерантністю у взаєминах з іншими, високими духовними запитами й гуманними орієнтирами. А розпочинається все 3 початкової школи.

Безумовно, вирішенню проголошеного завдання сприятимуть різні аспекти навчально-виховної роботи зі школярами, але чільне місце тут належить формуванню якісної мовленнєво-комунікативної компетентності. Не випадково Державний стандарт початкової освіти (2018 рік), перераховуючи цілу низку ключових компетентностей, на перше місце ставить саме вільне володіння українською мовою як державною, «що передбачає вміння усно і письмово висловлювати свої думки, почуття, чітко та аргументовано пояснювати факти, а також любов до читання, відчуття краси слова, усвідомлення ролі мови для ефективного спілкування та культурного самовираження, готовність вживати українську мову як рідну в різних життєвих ситуаціях» (Державний стандарт початкової освіти, 2018). Як бачимо, мовна підготовка передбачає значно більше, ніж суто лінгвістичний показник. Так, Т. Горбушко наголошує, що комунікативна компетентність напряму пов'язана з творчою самореалізацією індивіда в демократичному суспільстві (Горбушко, б.д.), Л. Ляшенко ж не просто відзначає взаємозалежність процесу оновлення змісту освіти 3 духовним розвитком молодших поколінь, а розглядає комунікативно-мовленнєву компетентність як прояв інтелекту й рівня мислення індивіда, «його освіченість i вихованість, культурність і ціннісні орієнтири...» (Ляшенко, б.д.). I подібні міркування можна відзначити в працях багатьох дослідників (Бобчук, 2016; Вашуленко, 2017; Конопельнюк, б.д.; Мудрик, 2017).

Тож проблема мовленнєво-комунікативної компетентності, у світлі набутою нею суспільної вагомості, передусім потребує поглибленого вивчення, виявлення чинників, які обумовлюють не стільки реалізацію навчальнодидактичної мети підготовки учнів початкових класів, скільки гарантують їхню соціалізацію, здатність упевнено почуватися в сучасному доволі неоднозначному середовищі 3 позицій оволодіння належними моральноетичними, культурологічно-духовними якостями, що визначатимуть їхню особистісну вагомість. Отже, розгортання нашого дослідження в подібному напрямку й визначатиме актуальність цієї розвідки.

Професіоналізм педагога: теоретичні й методичні аспекти. - Вип. 11. - Слов’янськ, 2019. 
Аналіз останніх досліджень і публікацій. Ознайомлення 3 працями, присвяченими дослідженню мовленнєво-комунікативної компетентності, дозволило розподілити їх мінімум на три групи. По-перше, теоретичні роботи, в яких розглядається сама сутність, природа, значимість мовленнєвокомунікативної компетентності (Артюшкіна, Рудь, б.д.; Мовленнєва компетентність дітей. Консультація для вихователів, б.д.; Орап, б.д.). Так, автори консультативного матеріалу з приводу розвитку мовленнєвої компетентності дітей зазначають, що мовленнєва компетентність - «це вміння адекватно й доречно користуватися мовою в конкретних ситуаціях (висловлювати свої думки, бажання, наміри, прохання тощо), використовувати для цього як мовні, так і позамовні (міміка, жести, рухи) та інтонаційні засоби виразності» (Мовленнєва компетентність дітей. Консультація для вихователів, б.д.). У цьому разі вагомість мовленнєвої компетентності розглядається тільки через призму лінгвістично-комунікативних умінь і навичок.

По-друге, статті безпосередньо пов'язані з практикою проведення уроків української мови та літературного читання в початкових класах. На наш погляд, деякі 3 них також хибують тим, що проблема мовленнєво-комунікативної компетентності розглядається в доволі вузьких навчально-дидактичних межах. Наприклад, ставиться завдання розвитку аудіативних умінь, формування діалогічної та монологічної вправності (Пономарьова, б.д.).

Коли ж ідеться про уроки літературного читання, то також часто акцент робиться лише на дидактичних можливостях матеріалу, що вивчається. Н. Биканова, формулюючи мету уроку за темою «Леся Українка „Біда навчить”», уважає, що необхідно «розвивати зв’язне мовлення, медіаграмотність; викликати інтерес до народної мудрості, до творів письменниці та бажання вчитися» (Биканова, 2019). Ми не проти такого формулювання мети уроку, але, як бачимо, зовсім не враховано виховний громадянський потенціал уроку, бо дотичність учнів до постаті та творчості Лесі Українки відкриває перед учителем та його учнями певні соціокультурологічні можливості. Значно звужує розвивальновиховну спрямованість уроку й Л. Діхтяренко (тема «Урок літературного читання в 2 класі з використанням технології критичного мислення»), убачаючи такий зміст формування ключових компетентностей: «уміння вчитися: здатність сприймати мету, яку ставить учитель, відповідно до неї планувати і виконувати певні дії <..>; соціальні: формувати вміння співпрацювати в групі, парі; загальнокультурні: сприяти дотриманню правил на уроці та норм мовленнєвої культури» (Діхтяренко, 2019: 14). 
Заявлені цілі мають доволі традиційне формулювання й зовсім не відбивають змістово-проблемні особливості твору Т. Стус «Смугастик», на грунті яких дійсно можна було б формувати вміння критично мислити, дискутувати, аргументувати власну позицію, беручи до уваги контраргументи співрозмовника.

По-третє, є низка статей, автори яких значно по-іншому підходять до розуміння змістового наповнення поняття «мовленнєво-комунікативна компетентність». Вони також пропонують застосовувати на уроці літературного читання різноманітні ігри (Дмитрук, 2015), інтерактивні технології (Левицька, б.д.) тощо. Однак ця «техніка» не затуляє глибинних завдань формування мовленнєво-комунікативних компетентностей, відбиваючи сучасні тенденції суб'єкт-суб' єктних стосунків, які повинні превалювати на уроці у взаєминах між учителем та учнем, що неодмінно позначиться на утвердженні позитивних особистісних якостей школяра: «На сучасному уроці навчальна взаємодія (викладання-учіння) має бути дитинно центрованою, забезпечувати розвиток кожної дитячої особистості, вносити свою лепту в соціальну й освітню підготовку дітей шляхом формування предметних і ключових компетентностей» (Савченко, 2012: 337). Тому в подальшому ми орієнтуватимемося на пропозиції та рекомендації авторів саме цих робіт.

Формулювання цілей статті. Зважаючи на здійснений нами огляд методичних напрацювань, висловлених із приводу них зауважень і міркувань, метою цієї розробки вбачаємо:

- увиразнення соціально-гуманітарної спрямованості роботи під час формування в учнів мовленнєво-комунікативної компетентності на уроках літературного читання;

- окреслення логістики переходу від одного рівня мовленнєвокомунікативної компетентності до іншого залежно від класу, у якому навчається дитина;

- осмислення доцільності й ефективності застосування різноманітних методичних прийомів і форм роботи під час вивчення конкретного художнього твору, зважаючи на його змістово-художні особливості.

Результати дослідження. У Державному стандарті початкової освіти чітко окреслені кінцеві параметри, які повинні демонструвати учні $1-2$ та 3 - 4 класів. На реалізацію та досягнення цих показників і повинна спрямовуватися вся діяльність учителя 3 урахуванням, безумовно, характеру літературнохудожнього матеріалу, що вивчається на уроці. Не будемо перераховувати всі критерії, але виокремимо ті, які, на наш погляд, несуть у собі особистісно 
розвивальні можливості. Це здатність висловлювати й захищати власні погляди, регулювати власний емоційний стан, збагачувати естетичний та емоційночуттєвий досвід, читати творчо, використовувати знання з мови в мовленнєвій творчості (Державний стандарт початкової освіти, 2018). Практичну реалізацію щодо досягнення цих результатів навчання ми і спробуємо продемонструвати на прикладі обраних творів 3 програми літературного читання для 2, 3 та 4-го класів.

У 2-му класі зупиняємося на народній казці «Їжак та заєць», уміщеній у підручнику Л. Йолкіної та Г. Волкотруб (Йолкіна, Волкотруб, 2019). Вивчення казок про тварин, а саме до цього різновиду належить обраний твір, відкриває перед учителем широкі навчально-виховні можливості. Адже кожен персонаж це людський тип, характер, тому при переказуванні тексту (відпрацьовується монологічне мовлення) обов'язково звертається увага на те, щоб діти висловлювали своє ставлення до дійових осіб (формування особистісної життєвої позиції), а, працюючи в парах (розвиток діалогічного мовлення) над головними образами казки, дискутували між собою, висловлювали власні судження, привчалися відстоювати й захищати власні переконання. Доцільною буде й інсценізація окремих фрагментів, що підштовхне учнів до мовленнєвих імпровізацій, коли через особливості промовляння окремих реплік Їжака та Зайця треба не лише передати характер дійової особи, а й своє ставлення до неї.

Цілком оригінальними видаються й завдання творчого характеру. Спочатку слід запропонувати прокоментувати ситуацію, що складається в казці, як із погляду Зайця, так і Їжака. Це неодмінно викличе потребу вжитися в персонажа, опинитися самому на його місці, а відтак опиратися на власні морально-етичні переконання, щоб у повній мірі збагнути наміри дій і бажань героїв. А це посприяє утвердженню тих духовних якостей, за якими повинні будуватися взаємостосунки між людьми.

Логічним продовженням цієї роботи стане така: змінити інтенційність перш за все Зайця, подумати, як від цього зміниться поведінка Їжака, а відтак і зробити висновки відносно того, що потрібно людям для нормальних стосунків.

Як бачимо, запропонований напрямок роботи над казкою цілком відповідає дидактично-методичним основам вивчення цього жанру i тим психічно-емоційним переживанням, які властиві дітям-другокласникам. А позитивним тут буде те, що, працюючи над текстом та образами, школярі проходитимуть «курс» соціалізації.

Для 3-го класу ми обрали оповідання В. Сухомлинського «Соромно перед соловейком» (підручник О. Савченко (2013), вивчення якого відбуватиметься на основі методу проєкту. Його перевага вбачається в тому, що проєктне навчання 
«полягає в моделюванні та здійсненні процесу розв’язання значущих для дітей цілей, проблемних задач і ситуацій, що вимагають пошуків, досліджень, співпраці між собою і дорослими» (Савченко, 2015: 26). Тобто сама технологія виконання проєкту потребує доволі тривалого часу (у 3-му класі - до 2-х тижнів), упродовж якого діти перебуватимуть в атмосфері творчого пошуку, знаходження і критичного осмислення необхідної інформації, постійно контактуватимуть між собою та з дорослими, що вдосконалюватиме суб'єкт - суб'єктні стосунки. Сам же проєкт ми пропонуємо здійснювати за алгоритмом, запропонованим О. Савченко (Савченко, 2015, с. 28):

\begin{tabular}{|c|c|c|c|}
\hline Назва & $\begin{array}{c}\text { Мета } \\
\text { (учитель - учні) }\end{array}$ & $\begin{array}{c}\text { Джерела } \\
\text { інформації }\end{array}$ & $\begin{array}{c}\text { Форми } \\
\text { презентації } \\
\text { результату } \\
\text { проєкту }\end{array}$ \\
\hline Людина & Учитель: & Ознайол & Індивідуа \\
\hline довкілля & ставлення дитини до & відеомат & продукт: \\
\hline Тип & природи, довкілля & «Як говорити 3 & конкурс творів- \\
\hline міжпредметний. & поглибити & дітьми & роздумів \\
\hline Задача: & морально- & екологію & «Екологічна \\
\hline розкрити & естетичні & https://osvitoria.me & загроза i що я \\
\hline підпорядкованіс & позиції & dia/experier & зробити \\
\hline ть взаємин між & усвідомити & -govoryty & для \\
\hline людиною & життєві критерії при & ekolog & подолання». \\
\hline рослинним $-\mathrm{i}$ & спілкуванні & «Екологі & Виставка \\
\hline тваринним & довкіллям, & https://uk. & оормаційне \\
\hline світом. & визначити . & a.org/wik & $\mathrm{Ta}$ \\
\hline Тривалість & особистісні & Я», & (дт \\
\hline тижні. & op & «Екологія. & M \\
\hline Результат & поводження & книга & Інтернет-сайти \\
\hline учня): & колективі; розвивати & http://odb.poltava. & щодо \\
\hline формулювання & правильно & ua/pdf/EKOLOGIJ & екологічної \\
\hline понять & визначати & a_D», «Екологічні & проблематики). \\
\hline $\begin{array}{l}\text { «природа», } \\
\text { «природоохорон }\end{array}$ & $\begin{array}{l}\text { роботи, } \quad \text { укладати } \\
\text { план та логістику ї }\end{array}$ & $\begin{array}{l}\text { проблеми землі», } \\
\text { «Екологічні }\end{array}$ & $\begin{array}{l}\text { Визнач } \\
\text { найкрал }\end{array}$ \\
\hline робота», & реалізації; привчати & проблеми & виконавців \\
\hline «екологія», & визначати голог & України» & інсценізованого \\
\hline «екологічна & другорядне в об’єкті & запропонувати & діалогу \\
\hline свідомість», & дослідження, & власний план & Олею та Лідою \\
\hline $\begin{array}{l}\text { укладання } \\
\text { графічної схеми }\end{array}$ & $\begin{array}{l}\text { знаходити адекватн1 } \\
\text { мовленнєві форми та }\end{array}$ & $\begin{array}{l}\text { можЛивих } \\
\text { екологічних }\end{array}$ & $\begin{array}{l}\text { В. Сухомлинськ } \\
\text { СПовання }\end{array}$ \\
\hline взаємин & засоби & заходів та дій. & «Соромно \\
\hline
\end{tabular}




\begin{tabular}{|c|c|c|c|}
\hline $\begin{array}{l}\text { рослинним } \\
\text { тваринним та } \\
\text { людським } \\
\text { світами, } \\
\text { інсценізація } \\
\text { діалогу між } \\
\text { Олею та Лідою з } \\
\text { приводу } \\
\text { дотримання } \\
\text { норм поведінки } \\
\text { у лісі } \\
\text { (оповідання } \\
\text { В. Сухомлинськ } \\
\text { ого «Соромно } \\
\text { перед } \\
\text { соловейком»), } \\
\text { розробка } \\
\text { сценарію гри «Я } \\
\text { зелений } \\
\text { патруль». }\end{array}$ & $\begin{array}{l}\text { переконливої } \\
\text { реалізації } \\
\text { сформульованого } \\
\text { завдання. } \\
\text { Учні: отримати } \\
\text { інформацію про } \\
\text { сутність поняття } \\
\text { «довкілля», } \\
\text { визначити місце } \\
\text { людини в тріаді } \\
\text { «флора - фауна - } \\
\text { людина», збагнути } \\
\text { відмінності } \\
\text { природоохоронній } \\
\text { та екологічній } \\
\text { діяльності, } \\
\text { привчатися } \\
\text { екологічно мислити } \\
\text { та діяти, самостійно } \\
\text { підібрати художній } \\
\text { твір, в якому б } \\
\text { порушувалися } \\
\text { екологічні } \\
\text { проблеми. }\end{array}$ & $\begin{array}{l}\text { Записати спогади } \\
\text { рідних (бабусі та } \\
\text { дідусі, мати, } \\
\text { батько, старші } \\
\text { брати та сестри) } \\
\text { про стан довкілля } \\
\text { часів їхного } \\
\text { дитинства. } \\
\text { Укласти каталог } \\
\text { (дані } \\
\text { шкільної/районно } \\
\text { ї/сільської/міської } \\
\text { бібліотеки, } \\
\text { Інтернет-сайти) } \\
\text { книжкових } \\
\text { видань, статей, } \\
\text { відеоматеріалів, } \\
\text { присвячених } \\
\text { екологічній } \\
\text { проблематиці. } \\
\text { Написати твір- } \\
\text { роздум } \\
\text { «Екологічна } \\
\text { загроза і шо я } \\
\text { можу зробити для } \\
\text { їі подолання». }\end{array}$ & $\begin{array}{l}\text { перед } \\
\text { соловейком»). } \\
\text { «Круглий стіл» } \\
\text { «У чому я бачу } \\
\text { екологічні } \\
\text { проблеми } \\
\text { нашого } \\
\text { населеного } \\
\text { пункту та шляхи } \\
\text { їх подолання». }\end{array}$ \\
\hline
\end{tabular}

Переконані, що робота над цим проєктом налаштує третьокласників на вдумливе опрацювання оповідання В. Сухомлинського, коли дії й учинки подружок розцінюватимуться не просто з позиції «Так чинити можна, а так - ні», а $з$ огляду на здобуті в ході виконання проєкту екологічні знання й усвідомлення необхідності дбати про довкілля як одну з пріоритетних ознак особистості, що перебуває й живе в сучасних умовах. Так формуватимуться громадянські позиції, що кожним своїм учинком, дією ти береш на себе відповідальність за екологічну безпеку середовища, в якому мешкаєш, дбаєш за екологічне здоров'я всієї планети.

Із програми 4-го класу ми обрали оповідання Гр. Тютюнника «Ласунка» (Савченко, 2015, с. 67) 3 доволі казковою фабулою (дружні взаємини рибалки Арсена та лисиці Ласунки), що потребує й відповідних методичних прийомів вивчення, 3-поміж яких ми зупинилися на ігрових вправах. Цей вибір не 
випадковий, бо, як зазначає 3. Дмитрук, сучасні «педагоги вбачають у грі можливості ефективної взаємодії та співпраці вчителя та учнів, продуктивного спілкування 3 елементами змагальності, безпосередності, природного інтересу» (Савченко, 2015, с. 19). Тобто гра на уроці сприяє особистісному зростанню дитини, адже стимулюються іiі психоемоційні потенції, набуваючи базового статусу в процесі волевиявлення індивіда. Звертаючись до тих чи тих ігрових вправ, ми відштовхуємося від пропозицій М. Левицької (Левицька, б.д.).

Як нам видається, дидактично-виховне спрямування уроку повинне полягати у формуванні таких почуттів, як доброзичливість, товариськість, уважність та взаєморозуміння. Наголосити на цих якостях можна під час здійснення таких ігрових вправ. Так, аналізуючи образи Арсена та Ласунки, доречно вдатися до гри «Павутинка»: учні «снують» дві павутинні мережі, у центрі однієї знаходиться образ Арсена, а іншої - Ласунка. Навколо них прописуються морально-душевні якості кожного з персонажів, а в разі збігу окремих рис неодмінно з'ясовуються причини цього.

Зацікавлення викличе і гра «Інтерв’ю» (робота в групах): розглядаючи ілюстрацію в підручнику, необхідно пригадати, якого епізоду вона стосується, які риси характерів усіх дійових персонажів розкриваються при цьому, а на підставі цього взяти «інтерв'ю» в кожного 3 них. Це дозволить збагнути прагнення кожного учасника риболовлі, виявляючи при цьому особливості ставлення один до одного, а потім провести обговорення, яке «інтерв'ю» виявилося найкращим. Завдяки цьому учні вироблятимуть не лише власні життєві позиції, а й уміння порозумітися з іншим, збагнути його бажання та прагнення.

Заключним етапом у роботі над оповіданням може стати гра «Крісло автора», коли школярам пропонується дописати ймовірне продовження представленої Гр. Тютюнником історії, або зберігаючи виявлені риси характеру рибалки, Ласунки та їі дитинчати, або вносячи власні корективи та доповнення. Так стимулюватимуться творчі якості учнів, розвиватимуться їхні мовномовленнєві здібності, утверджуватимуться комунікативні здібності залежно від ситуації, в якій вони можуть опинитися.

Висновки 3 дослідження і перспективи подальших розвідок у цьому напрямі. Отже, ми переконані, що формування мовленнєво-комунікативної компетентності не повинне замикатися лише на дидактичних завданнях уроку, а неодмінно спрямовуватися на виховання особистості 3 чітко вираженими громадянськими позиціями. Тому в подальшому слід зосередитися на: 


\section{В. СИРОТЕНКО, А. АКРИТОВА}

Особливості формування мовленнєво-комунікативної компетентності на уроках літературного читання в $2-4$ класах

- осмисленні дієвості інших методичних прийомів, до яких варто вдаватися вчителеві, працюючи над розвитком мовленнєво-комунікативної компетентності;

- визначити вагомість інших дидактичних компетентностей у справі виховання особистісно-громадянських якостей учнів;

- розкрити логічний взаємозв'язок окремих компетентностей щодо їхньої виховної спроможності.

\section{СПИСОК ВИКОРИСТАНИХ ДЖЕРЕЛ}

1. Артюшкіна, Л. М., Рудь О. М. (б.д.). Мовленнєва компетентність як складова комунікативного процесу державних службовців. Взято з https://www.google.ru/url

2. Биканова, Н. (2019). Урок літературного читання, 4 клас. Початкова школа, 2, 1618.

3. Бобчук, О. (2016). Напрями роботи з розвитку умінь мовленнєвої діяльності у молодших школярів. Початкова школа, 1, 9-14.

4. Вашуленко, О. (2017). Формування комунікативно-мовленнєвих умінь молодших школярів на уроках літературного читання. Початкова школа, 8, 20-24.

5. Горбушко, Т. Г. (б.д.). Шляхи формування комунікативної компетентності

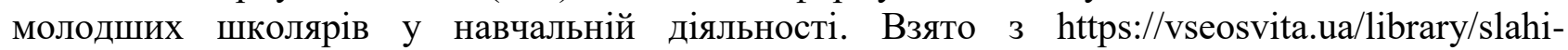
formuvanna-komunikativnoi-kompetentnosti-molodsih-skolariv-u-navcalnij-dialnosti-100786.html

6. Державний стандарт початкової освіти. (2018). Взято 3 http://dano.dp.ua/attachments/article/303/Державний\%20стандарт\%20початкової\%20освіти.pdf

7. Діхтяренко, Л. (2019). Урок літературного читання у 2 класі з використанням технології критичного мислення. Початкова школа, 3, 14-18.

8. Дмитрук, 3. (2015). Дидактичні та інтелектуальні ігри під час опрацювання казок Івана Франка. Початкова школа, 6, 9-20.

9. Йолкіна, Л. В., Волкотруб, Г. Й. (2019). Українська мова та читання. 2 клас. Підручник для 2 класу закладів загальної середньої освіти. У двох частинах. Частина 2. Київ, Украъна: Генеза.

10. Конопельнюк, М. В. (б.д.). Формування комунікативної компетентності учнів початкових класів на уроках української мови. Взято з www.moskovskiy-ruo.edu.kh.ua/

11. Левицька, М. (б.д.). Формування мовленнєвої компетентності молодших школярів. Взято $3 \mathrm{http} / /$ ukped.com/ukrainska-mova-ta-literatura/5709-formuvannya-movlennyevoyikompetentnosti-molodshykh-shkol

12. Ляшенко, Л. Є. (б.д.). Формування мовленнєво-комунікативних компетенцій на уроках рідної мови в початкових класах. Взято 3 https://naurok.com.ua/formuvannyamovlennevo-komunikativnih-kompetenciy-na-urokah-ridno-movi-v-pochatkovih-klasah-

24844.html

13. Мовленнєва компетентність дітей. Консультація для вихователів. (б.д.). Взято 3 https://www.google.ru/url

14. Мудрик, О. (2017). Формування громадянської компетентності учнів засобами використання краєзнавчого матеріалу. Початкова школа, 12, 30-33.

15. Орап, М. О. (б.д.). Мовленнєва компетентність як структурний елемент мовленнєвої організації суб'єкта: теоретичний аналіз. Взято 3 http://nbuv.gov.ua/UJRN/psling_2009_4_12

16. Пономарьова, К. (б.д.). Формування мовленнєвої компетентності молодших $\begin{array}{lllll}\text { школярів на } & \text { уроках } & \text { української }\end{array}$ 


\title{
В. СИРОТЕНКО, А. АКРИТОВА
}

Особливості формування мовленнєво-комунікативної компетентності на уроках літературного читання в $2-4$ класах

http://lib.iitta.gov.ua/8027/1/Формування_мовленнєвої_компетентності_молодших_школярів.p df

17. Савченко, О. (2015). Літературне читання. 4 клас : підруч. для загальноосвіт. навч. закл. Київ, Україна: Видавничий дім «Освіта».

18. Савченко, О. (2015). Метод проектів на уроках літературного читання. Початкова школа, 11, 26-31.

19. Савченко, О. Я. (2012). Дидактика початкової освіти: підручн. Київ, Україна: Грамота.

20. Савченко, О. Я. (2013). Літературне читання. Українська мова. 3 клас : підруч. для загальноосвіт. навч. закл. Київ, Україна: Видавничий дім «Освіта».

\section{THE FEATURES OF DEVELOPING THE SPEECH AND COMMUNICATIVE COMPETENCE IN LITERARY READING LESSONS IN THE $2^{\text {nd }}-4^{\text {th }}$ FORMS}

\author{
Valerii Syrotenko \\ Candidate of Philological Sciences, Associate Professor \\ SHEE "Donbas State Pedagogical University" \\ Sloviansk, Donetsk region, Ukraine \\ valerij.s.kram@gmail.com
}

\author{
Anastasiia Akrytova \\ Teacher of the Highest Category \\ PI "Pokrovsk Pedagogical College" \\ Pokrovsk, Donetsk region, Ukraine
}

\begin{abstract}
The article looks into the consideration of peculiarities of developing the speech and communicative competence in lessons of literary reading (the grades $2-4$ ). At present, this is an extremely relevant problem, as the purposeful work on the development of speech and communicative qualities belongs to one of the leading educational tasks of the New Ukrainian School. In addition, the level of speech and communicative competence is a testament to the personal development of a student. The conditions of its implementation are emphasised in the study, with the selection of works of art, the analysis of which can be carried out using different methodological techniques.

Thus, when studying the folk tale "Hedgehog and Hare" in the $2^{\text {nd }}$ form, considering the typological peculiarities of folklore works (each character is a human type, a personality), the focus is on text rendering (monologic speech development) and working in pairs (dialogic speech development), but the task is that children must express their attitude to the characters, which affects the formation of personal life position. It is advisable to stage certain fragments, which will encourage students to make speech improvisations, when due to the peculiarities of speaking some Hedgehog and Hare's replicas, one must not only convey the character of the actor, but also his attitude towards him. The authors offer the creative tasks: commentary on the situation from the point of view of different characters, change in intentionality, which helps to obtain the communicative ability to navigate the emerging situation, taking into account the aspirations of others.

The work on V. Sukhomlynskyi's story "Shame on the Nightingale" (the $3^{\text {rd }}$ form) is carried out through the project method ("Man and Environment"). Its task is to develop the students' environmental consciousness as an integral part of the civic personality traits. The project implementation technology takes a long time, during which children will be in an atmosphere of
\end{abstract}

Професіоналізм педагога: теоретичні й методичні аспекти. - Вип. 11. - Слов'янськ, 2019. 


\section{В. СИРОТЕНКО, А. АКРИТОВА}

Особливості формування мовленнєво-комунікативної компетентності на уроках літературного читання в $2-4$ класах

creative searching, finding and critical understanding of the necessary information, will constantly be in contact with each other and with adults, which will improve the subject-subjective relationship. The work on this project will set the third-graders to thoughtful elaboration of V. Sukhomlynskyi's story, when the actions of the friends will be evaluated not simply from the position "You can do it or not", but considering the ecological knowledge and awareness acquired during the implementation of the project about the environment as one of the priority features of a person who lives in modern conditions.

In the analysis of the story of Hr. Tiutiunnyk "Lasochka" (the $4^{\text {th }}$ form) with a rather fabulous plot (friendly relations between the fisherman Arsen and the fox Lasunka) the authors propose to apply to gaming exercises that will enhance the students' intellectual abilities, developing the potential to act in a precarious situation with respect to the accessory communication, confirming significant moral qualities of the personality. When analysing the images of Arsen and Lasunka, it is appropriate to use the game "Spider Web": students make two spider webs, there is the image of Arsen in the centre of one and Lasunka in the other. They describe moral and spiritual qualities of each of the characters, and in the case of coincidence of individual traits, the reasons for this are inevitably explained. The interview game is conducted in groups: considering the illustration in the textbook, it is necessary to remember which episode it relates to, which personality traits are revealed and based on this, to "interview" each of the characters. Through this, students will develop not only their own life positions, but also the ability to communicate with others, to understand their desires and aspirations. The final stage of the work is the game "The Author's Chair", when students are asked to add a possible continuation of the story presented by Hr. Tiutiunnyk, either by retaining the fisherman, Lasunka and her cubs' traits, or by making their own adjustments and additions. This will stimulate the students' creative qualities, develop their language and speech abilities, and enhance communicative skills depending on the situation.

Key words: speech and communicative competence; personality; dialogic speech; monologic speech; working in pairs; working in groups; intention; project method; gaming exercises; ecology; ecological consciousness; moral and ethical qualities.

\section{REFERENCES (TRANSLATED AND TRANSLITERATED)}

1. Artiushkina L. M., Rud O. M. (n.d.). Speech competence as a component of the communication process of civil servants. Retrieved from https://www.google.ru/url

2. Bykanova, N. (2019). Literary reading lesson, form 4. Pochatkova shkola, 2, 16-18.

3. Bobchuk, O. (2016). Areas of work for the development of speech skills in younger students. Pochatkova shkola, 1, 9-14.

4. Vashulenko, O. (2017). Formation of communicative and speaking skills of younger students in literary reading lessons. Pochatkova shkola, 8, 20-24.

5. Horbushko, T. H. (n.d.). Ways of formation of communicative competence of younger pupils in educational activity. Retrieved from https://vseosvita.ua/library/slahi-formuvannakomunikativnoi-kompetentnosti-molodsih-skolariv-u-navcalnij-dialnosti-100786.html

6. State standard of primary education. (2018). Retrieved from http://dano.dp.ua/attachments/article/303/Derzhavnyi\%20standart\%20pochatkovoi\%20osvity.pdf

7. Dikhtiarenko, L. (2019). Literary reading lesson in grade 2 using critical thinking technology. Pochatkova shkola, 3, 14-18.

8. Dmytruk, Z. (2015). Didactic and intellectual games in the development of Ivan Franko's fairy tales. Pochatkova shkola, 6, 9-20.

9. Iolkina, L. V. \& Volkotrub H. Y. (2019). Ukrainian language and reading. Form 2. A textbook for 2nd form general secondary education institutions. In two parts. Part 2. Kyiv, Ukraine: Heneza.

10. Konopelniuk, M. V. (n.d.). Formation of communicative competence of elementary school students in the Ukrainian language lessons. Retrieved from www.moskovskiy-ruo.edu.kh.ua/ 


\section{В. СИРОТЕНКО, А. АКРИТОВА}

Особливості формування мовленнєво-комунікативної компетентності на уроках літературного читання в $2-4$ класах

11. Levytska, M. (n.d.). ormation of speech competence of younger students. Retrieved from http://ukped.com/ukrainska-mova-ta-literatura/5709-formuvannya-movlennyevoyi-kompetentnostimolodshykh-shkol

12. Liashenko, L. Ye. (n.d.). Formation of speech and communicative competences in native language lessons in elementary classes.. Retrieved from https://naurok.com.ua/formuvannyamovlennevo-komunikativnih-kompetenciy-na-urokah-ridno-movi-v-pochatkovih-klasah24844.html

13. Speech competence of children. Advice for educators. (n.d.). Retrieved from https://www.google.ru/url

14. Mudryk, O. (2017). Formation of students' civic competence by means of using local country study material. Pochatkova shkola, 12, 30-33.

15. Orap, M. O. (n.d.). Speech competence as a structural element of a subject's speech organization: A theoretical analysis. Retrieved from http://nbuv.gov.ua/UJRN/psling_2009_4_12

16. Ponomarova, K. (n.d.). Formation of speech competence of younger students in Ukrainian language lessons. $\quad$ Retrieved from http://lib.iitta.gov.ua/8027/1/Formuvannia_movlennievoi_kompetentnosti_molodshykh_shkoliariv. pdf

17. Savchenko, O. (2015). Literary reading. Grade 4: textbook. for general secondary education institution. Kyiv, Ukraine: Vydavnychyi dim "Osvita".

18. Savchenko, O. (2015). Project method for literary reading lessons. Pochatkova shkola, $11,26-31$.

19. Savchenko, O. Ya. (2012). Didactics of primary education: textbook. Kyiv, Ukraine: Hramota.

20. Savchenko, O. Ya. (2013). Literary reading. Ukrainian language. Form 3: textbook. for secondary education institutions. Kyiv, Ukraine: Vydavnychyi dim "Osvita".

Матеріали надійшли до редакції 03.12.2019 p. 